\title{
Effect of Soil Microbiome from Church Forest in the Northwest Ethiopian Highlands on the Growth of Olea europaea and Albizia gummifera Seedlings under Glasshouse Conditions
}

\author{
Getu Abebe ${ }^{1,2, *}$, Atsushi Tsunekawa $\left.{ }^{3}{ }^{(}\right)$, Nigussie Haregeweyn ${ }^{4}{ }^{(}$, , Takeshi Taniguchi ${ }^{3}$, \\ Menale Wondie ${ }^{2}{ }^{(D}$, Enyew Adgo ${ }^{5}{ }^{\oplus}$, Tsugiyuki Masunaga ${ }^{6}$, Mitsuru Tsubo ${ }^{3}$, Kindiye Ebabu ${ }^{3,5}$, \\ Amrakh Mamedov ${ }^{3}$ and Derege Tsegaye Meshesha ${ }^{5}$ \\ 1 The United Graduate School of Agricultural Sciences, Tottori University, 4-101 Koyama-minami, \\ Tottori 680-8553, Japan \\ 2 Amhara Agricultural Research Institute, Forestry Research Department, P.O. Box 527 Bahir Dar, Ethiopia; \\ menalewondie@yahoo.com \\ 3 Arid Land Research Center, Tottori University, 1390 Hamasaka, Tottori 680-0001, Japan; \\ tsunekawa@tottori-u.ac.jp (A.T.); takeshi@alrc.tottori-u.ac.jp (T.T.); tsubo@tottori-u.ac.jp (M.T.); \\ kebabu@tottori-u.ac.jp (K.E.); amrakh03@yahoo.com (A.M.) \\ 4 International Platform for Dryland Research and Education, Tottori University, 1390 Hamasaka, \\ Tottori 680-0001, Japan; nigussie_haregeweyn@yahoo.com \\ 5 College of Agriculture and Environmental Sciences, Bahir Dar University, P.O. Box 1289 Bahir Dar, Ethiopia; \\ enyewadgo@gmail.com (E.A.); deremesh@yahoo.com (D.T.M.) \\ 6 Faculty of Life and Environmental Science Shimane University, Shimane Matsue 690-082, Japan; \\ masunaga@life.shimane-u.ac.jp \\ * Correspondence: gabebe233@gmail.com or d17a4114b@edu.tottori-u.ac.jp
}

Received: 3 April 2020; Accepted: 13 June 2020; Published: 18 June 2020

\begin{abstract}
Loss of beneficial microbes and lack of native inoculum have hindered reforestation efforts in the severely-degraded lands worldwide. This is a particularly pressing problem for Ethiopia owing to centuries-old unsustainable agricultural practices. This study aimed to evaluate the inoculum potential of soils from church forest in the northwest highlands of Ethiopia and its effect on seedling growth of two selected native tree species (Olea europaea and Albizia gummifera) under a glasshouse environment. Seedlings germinated in a seed chamber were transplanted into pots containing sterilized and/or non-sterilized soils collected from under the canopy of three dominant church forest trees: Albizia gummifera (AG), Croton macrostachyus (CM), and Juniperus procera (JP) as well as from adjacent degraded land (DL). A total of 128 pots ( 2 plant species $\times 4$ soil origins $\times 2$ soil treatments $\times 8$ replicates) were arranged in a factorial design. Overall, seedlings grown in AG, $\mathrm{CM}$, and JP soils showed a higher plant performance and survival rate, as a result of higher soil microbial abundance and diversity, than those grown in DL soils. The results showed significantly higher plant height, root collar diameter, shoot, and total mass for seedlings grown in non-sterilized forest soils than those grown in sterilized soils. Furthermore, the bacterial relative abundance of Acidobacteria, Actinobacteria, and Nitrospirae was significantly higher in the non-sterilized forest soils AG, CM, and JP $\left(\mathrm{r}^{2}=0.6-0.8, p<0.001\right)$. Soil $\mathrm{pH}$ had a strong effect on abundance of the bacterial community in the church forest soils. More specifically, this study further demonstrated that the effect of soil microbiome was noticeable on the performance of Olea seedlings grown in the soil from $\mathrm{CM}$. This suggests that the soils from remnant church forests, particularly from the canopy under $\mathrm{CM}$, can serve as a good soil origin, which possibly would promote the native tree seedling growth and survival in degraded lands.
\end{abstract}

Keywords: arid regions; bacteria; degraded land; fungi; ITS; microbial community; restoration; $16 \mathrm{~S}$ rRNA 


\section{Introduction}

Land degradation is a major global problem affecting all terrestrial biomes in arid and humid regions [1,2]. Human activities, such as deforestation, overgrazing, and improper agricultural practices are the main factors causing land degradation, all of which significantly reduce environmental quality, and socio-economic sustainability [3-6]. Land degradation also causes deterioration of soil communities and negatively influences ecosystem function [7]. Studies have revealed the significant role of soil microbes in ecosystem functioning [8,9]. However, the loss of beneficial microbes, including fungi and bacteria, adversely affects the recovery potential of a degraded ecosystem [10].

Symbiotic relationships between the roots of higher plants and microbes (fungi and bacteria) strongly influence plant survival, growth, and ecosystem properties [11]. These beneficial microbes can enhance soil nutrient supply, drought tolerance, and pathogen resistance [12] of the host plant. The interaction of soil microbes with plant roots and organic matter can improve soil aeration and resistance to slaking and erosion by enhancing soil aggregation and structural stability; the microorganisms influence soil aggregation via chemical stabilization, and the organic matter contributes a cementing effect [13]. However, these functional roles of soil microbes are limited in degraded ecosystems because of a low level of microbial diversity, poor vegetation cover, high soil disturbance, and severe erosion rates $[10,14,15]$. Consequently, in many regions of the world, various methods of ecological restoration are necessary to rectify degraded ecosystems [16]. For instance, soil and water conservation practices [17], including afforestation and exclosure establishment [2,18], have been experimented with within Ethiopia. However, achieving restored ecosystem function through re-establishment of native tree species [19] has proved challenging due to the lack of a native soil microbial community in degraded lands (DLs) [20]. Indeed, soil microbes in combination with plant species play a crucial role in restoring DL $[8,15]$. In the case of the Ethiopian highlands, very little information exists about the source of native inoculum for the successful restoration of lost microbial community functions in degraded landscapes.

Small patches of natural forest, called "church forests," exist around Ethiopian Orthodox Tewahedo churches and monasteries, and these constitute the last remnants of the original forest cover, having been conserved for more than a century. Church forests are located in a matrix of intensively degraded agricultural landscapes [21,22]. Apart from their social and spiritual value, church forests are obvious and important foci of biodiversity and act as a source of seeds and germplasm for native flora [21-24]. However, there is a lack of studies characterizing the role of microbial communities or evaluating the inoculum potential and the effects of microbes from church forests on the early stages of native tree establishment.

Olea europaea L. subsp. cuspidata and Albizia gummifera are among the most important native tree species of Ethiopia. These two tree species were selected for this study based on their social and ecological importance and their limited survival and regeneration ability in degraded lands of the Ethiopian highlands $[25,26]$. Olea europaea subsp. cuspidata (Wall. ex DC.) is a late-successional evergreen tree species found in dry Afromontane forest between 1250 and $3100 \mathrm{~m}$ a.s.l. [27]. The species is hardy and drought resistant once established, even in poor soils; adult trees are commonly $15-25 \mathrm{~m}$ high [28]. Albizia gummifera (J.F.Gmel.) C.A.Sm., is a deciduous tree species; it can reach up to $15 \mathrm{~m}$ height and occurs in semi-humid and humid highland forests between 1400 and $2500 \mathrm{~m}$ a.s.l. [28]. It often co-exists with Olea europaea and Juniperus procera [29]. Despite Olea europaea and Albizia gummifera are among the suitable native tree species supposed to restoring degraded lands in the highlands of Ethiopia, no or very limited information is available on the growth performance and survival rate of their seedlings in soils from conserved forest and degraded lands. This study was, therefore, designed to: (1) assess the soil microbial diversity in remnant church forest and surrounding degraded land, (2) evaluate the effect of soil microbiome, from under the canopy of church forest, on early growth and survival 
rate of seedlings of Olea europaea and Albizia gummifera under glasshouse conditions, and (3) evaluate the association between soil microbial and chemical properties in relation to plant growth.

\section{Materials and Methods}

\subsection{Site Description}

The study was conducted using soil sampled from Ethiopian Orthodox Tewahedo Church, Laguna St. Giorgis forest (Figure 1). Laguna St. Giorgis forest is a remnant forest around a church built in 1500 A.D. It is located at $11^{\circ} 39^{\prime} 21^{\prime \prime} \mathrm{N}$ and $37^{\circ} 30^{\prime} 36^{\prime \prime} \mathrm{E}$ at an altitude of $2100 \mathrm{~m}$ a.s.l. The current forest covers 5.25 ha. The mean annual rainfall ranges from 895 to $2037 \mathrm{~mm}$ (Figure 2a). The mean annual temperature range is $17-31^{\circ} \mathrm{C}$ [30]. The vegetation type of the area is Albizia-Juniperus-Croton-dominated dry Afromontane forest [31]. Leptosols and Regosols are the major soil types in the study area [32].

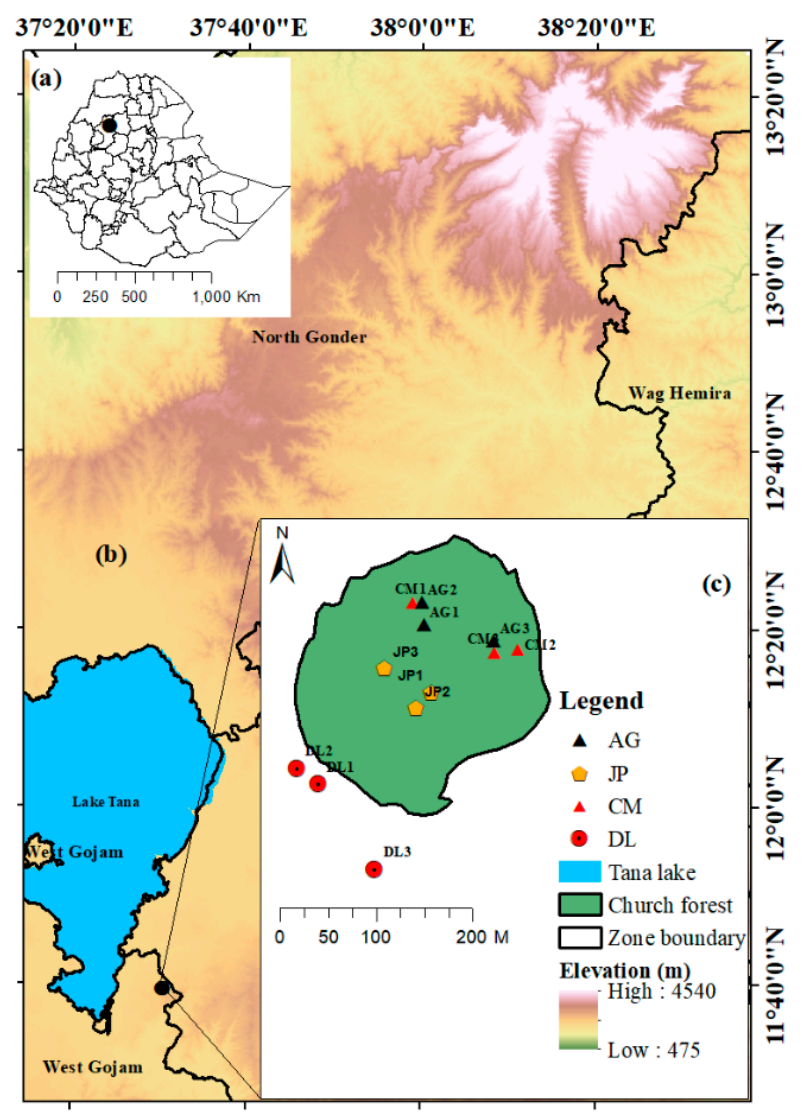

Figure 1. Location of the study area. The study site is indicated by the black circle (a,b). Albizia gummifera (AG), Croton macrostachyus (CM), Juniperus procera (JP) are tree species in the church forest, and DL is adjacent degraded land (c).

\subsection{Field Soil Sampling}

Soil samples were collected under the canopy of three predominant native tree species: Albizia gummifera (AG), Croton macrostachyus (CM), and Juniperus procera (JP), in the church forest (Figure 1c), as well as from adjacent degraded land (DL). For each tree species and DL, three replicate soil samples were collected from the top 0 to $20 \mathrm{~cm}$ soil depth using a ruler and a hand shovel measuring around $3.0 \mathrm{~kg}$ of soil in plastic bags. Soil samples from a similar source were mixed to obtain a composite inoculum. The samples were prepared at the soil laboratory of Bahir Dar University, Ethiopia, and transported to Japan for the experiment: half of the total samples for each soil origin were sterilized using gamma-rays (30-60 kGy; [33]) to evaluate the effects of soil microbes. For each soil 
origin, a $2 \mathrm{~g}$ sample was taken to store at $-80^{\circ} \mathrm{C}$ for downstream DNA extraction to evaluate soil microbiome before the Glasshouse $(\mathrm{GH})$ experiment.
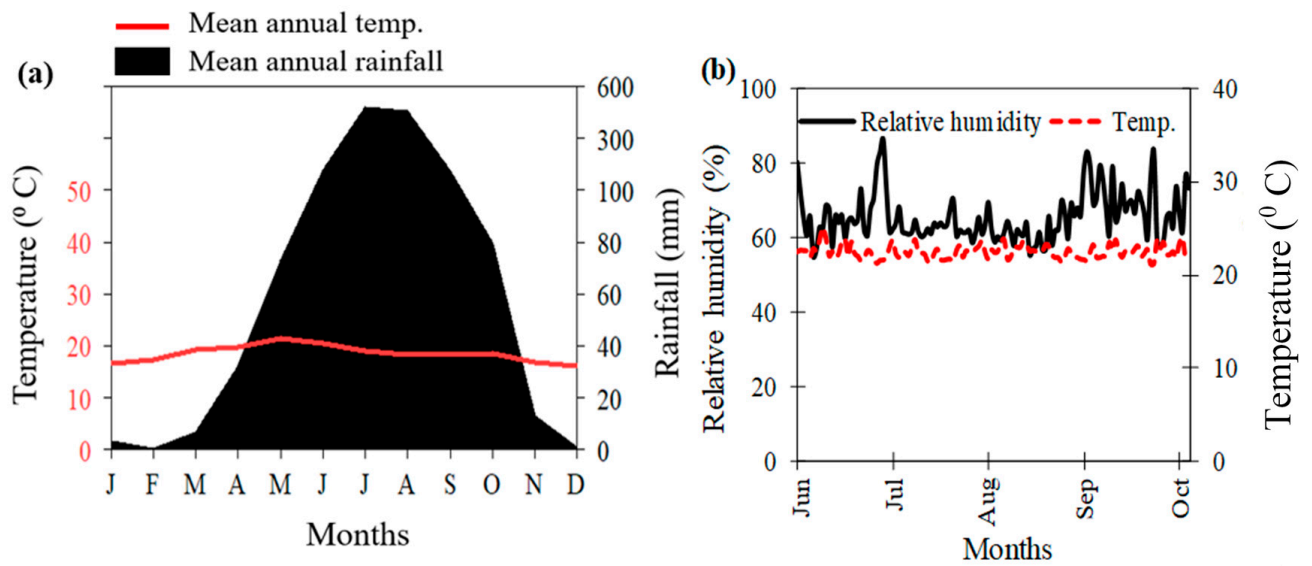

Figure 2. (a) Climate characteristics of the study area from 1962 to 2017 [30,34] and (b) glasshouse atmospheric conditions during the experiment. Climate diagram of the study site (a) is based on Walter and Lieth climate diagrams [35].

\subsection{Experimental Design}

A pot experiment was carried out in a glasshouse at Tottori University, Arid Land Research Center, Japan. The temperature in the glasshouse was in the range of $21-25^{\circ} \mathrm{C}$ with an average relative humidity of $65.7 \%$ (Figure $2 b$ ).

Surface-sterilized seeds of Olea and Albizia were germinated, in May 2018, using autoclaved vermiculite $\left(15 \mathrm{~min}\right.$ at $\left.121^{\circ} \mathrm{C}\right)$ in a seed germination chamber (MLR-351H, SANYO, Tokyo, Japan); temperature and relative humidity of the chamber was $25^{\circ} \mathrm{C}$ and $60-70 \%$, respectively. Albizia seeds were germinated in a week, while Olea seeds took 2 weeks after sowing in the chamber. The seedlings were transplanted to the glass pots ( $4 \mathrm{~cm}$ diameter and $14 \mathrm{~cm}$ height each) at the depth of $2-3 \mathrm{~cm}$ containing either sterilized or non-sterilized soil ( $100 \mathrm{~g}$ for samples from forest and $125 \mathrm{~g}$ for samples from degraded land). The pots were kept at room conditions $\left(25^{\circ} \mathrm{C}\right.$ and $12 \mathrm{~h}$ light) for 2 weeks.

A total of 128 pots ( 2 plant species $\times 4$ soil origins $\times 2$ soil treatments $\times 8$ replicates) were transferred to the glasshouse for further monitoring and evaluation. Pots were maintained at $15 \%$ moisture content throughout the experiment period ( 5 months) and were weighed every 3 days. Every 2 weeks, $10 \mathrm{~mL}$ of sterilized distilled water was added to the pots containing non-sterilized soil and, to control contamination, $10 \mathrm{~mL}$ of 1:50 antibiotic (penicillin/streptomycin/amphotericin B solution [36] and sterilized distilled water) solution was added to the pots containing sterilized soil.

\subsection{Growth and Survival Data}

Seedling survival was recorded monthly until the end of the GH experiment. Plant height $(\mathrm{cm})$ and root collar diameter ( $\mathrm{RCD}, \mathrm{mm}$ ) were measured using a ruler and digital caliper, respectively, at the end of the $\mathrm{GH}$ experiment. Root to shoot $(\mathrm{R} / \mathrm{S})$ ratio was calculated by dividing root dry weight by shoot dry weight.

\subsection{Soil Analysis}

Soil samples collected from field (before GH experiment) and pots (after the GH experiment) were air-dried, passed through a 2-mm sieve and analyzed for selected soil parameters: $\mathrm{pH}$, organic carbon, total nitrogen, available phosphorus $(\mathrm{P})$, aggregate-structure stability, and texture (particle size). Soil $\mathrm{pH}$ was measured in 1:2.5 soil: water suspension. Soil organic carbon (SOC) and total nitrogen (TN) were determined using a CN corder (Macro Corder JM1000CN, J-Science Lab, Kyoto, Japan). 
Soil available $\mathrm{P}$ was extracted with a solution of $1.0 \mathrm{M}$ ammonium fluoride and $2.5 \mathrm{M}$ hydrochloric acid (Bray II method; Bray and Kurtz [37]). Phosphate was detected by absorption spectrometry (UV-140-02; Shimadzu, Kyoto, Japan) using the molybdenum blue colorimetric procedure. Soil aggregate-structure stability (SAS) was determined using the modified high energy moisture characteristics method [38], and particle size was analyzed by the hydrometer method [39]. In addition, soil moisture content was gravimetrically measured after drying moist samples in an oven at $105^{\circ} \mathrm{C}$ for $24 \mathrm{~h}$ [39].

\subsection{Plant and Soil Sample Collection}

Seedlings were harvested at 5 months after transplantation (Figures S2 and S3). At harvest, for each seedling: (i) the shoots (stem and leaves) were separated and weighed, (ii) after breaking the glass pots, the roots were carefully separated, gently washed with tap water, and weighed in fresh. Shoots and roots were then dried at $60^{\circ} \mathrm{C}$ for $72 \mathrm{~h}$ and weighed to estimate the shoot, root and total biomass. From each pot, $2 \mathrm{~g}$ of soil samples were collected to store at $-80^{\circ} \mathrm{C}$ for further molecular microbiome characterization after the GH experiment.

\subsection{Soil DNA Extraction, Polymerase Chain Reaction (PCR) Amplification, and Sequencing}

For each sample, $0.25 \mathrm{~g}$ of soil was extracted using DNeasy PowerSoil ${ }^{\circledR}$ DNA kit (Qiagen, Germany) following the manufacturer's protocol. The extracted DNA solution was diluted 10 times and PCR was carried out using BIO-RAD T100 ${ }^{\mathrm{TM}}$ Thermal Cycler (Bio-Rad Laboratories, Hercules, CA). For each sample, two replicates were amplified in a $20 \mu \mathrm{L}$ (total volume) reaction mixture, containing $1 \mu \mathrm{L}$ of template DNA ( $10 \mathrm{ng} / \mu \mathrm{L}), 7.0 \mu \mathrm{L}$ sterilized distilled water, $10 \mu \mathrm{L}$ of $2 \times$ Q5 High-Fidelity DNA Polymerase (New England Biolabs Inc., Ipswich, MA, USA), and $1.0 \mu \mathrm{L}$ for each primer.

The V4 region in the 16S rRNA gene was amplified using primers S-D-Arch-0519-a-S-15 (CAGCMGCCGCGGTAA) and S-D-Bact-0785-a-A-21(GACTACHVGGGTATCTAATCC) for bacteria [40]. The internal transcribed spacer (ITS) region was amplified with the primers ITS1F_KYO2 (TAGAGGAAGTAAAAGTCGTAA) and ITS2_KYO2 (TTYRCTRCGTTCTTCATC) for fungi [41]. Each forward primer was tagged with the Ion Torrent specific adapters and Ion Xpress barcode to distinguish the origin of samples. The expected band size for $16 \mathrm{~S}$ rRNA and ITS primers was $350 \mathrm{bp}$ and $360 \mathrm{bp}$, respectively.

The PCR thermal cycling conditions were: initial denaturation at $98{ }^{\circ} \mathrm{C}$ for $30 \mathrm{~s}$, followed by 35 cycles of $98^{\circ} \mathrm{C}$ for $10 \mathrm{~s}, 53^{\circ} \mathrm{C}$ for $30 \mathrm{~s}$, and $72{ }^{\circ} \mathrm{C}$ for $1 \mathrm{~min}$, followed by a $2 \mathrm{~min}$ final extension at $72{ }^{\circ} \mathrm{C}$. The PCR products were checked by agarose gel electrophoresis, and the replicates were composited to make one mix for purification. The purified DNA concentration was quantified for each PCR product with the Qubit dsDNA HS Assay Kit on a Qubit fluorometer 2.0 (Invitrogen, Carlsbad, CA, USA). Then, pooled DNA distribution and size were checked using Agilent 2100 (Agilent Technologies, Inc. Santa Clara, CA, USA) after putting an equimolar amount of amplified DNA into a tube. Following this, DNA sequencing by Ion Torrent Personal Genome Machine (Life Technology, Inc. Carlsbad, CA, USA) was performed as described by [41].

\subsection{Sequence Data Processing}

Sequence data processing was performed as previously described in Tian et al. [42]. Quality sequences were gained using the Quantitative Insight into Microbial Ecology (QIIME) 1.8.0 pipeline [43] after removing sequences shorter than $200 \mathrm{bp}$ for bacteria and $360 \mathrm{bp}$ for fungi, and sequences with expected errors predicted by Phred $(\mathrm{Q})$ scores greater than 0.8. ITSx were used to precisely pick the ITS region for fungal DNA [44]. Successful sequences (Figure S1) were clustered into operational taxonomic units (OTUs) at 97\% similarity level using USEARCH [45]. Then, sequencing chimeras were checked and removed using UCHIME [46]. Taxonomy of each OTU was assigned to fungal and bacterial taxa using UNITE [47] and SILVA (SILVA 128 QIIME release) databases, respectively. 


\subsection{Statistical Analysis}

Statistical analyses were performed in R [48] using the interference implemented RStudio (version 1.1.383). The data were checked for normal distribution before analysis using the Shapiro-Wilk test, and non-normally distributed data were log and square-root transformed. The effects of soil from the four origins (DL, AG, CM, and JP) with soil treatment on plant height, $\mathrm{R} / \mathrm{S}$ ratio, mass, $\mathrm{pH}$, soil organic carbon $(\mathrm{SOC})$, total nitrogen $(\mathrm{TN})$, carbon/nitrogen $(\mathrm{C} / \mathrm{N})$ ratio, available $\mathrm{P}$, and SAS were analyzed with a general linear model procedure. Three-way ANOVA was used to check the effect of species on pooled plant and soil properties, then the two species (Olea and Albizia) separately and soil origins (with and without soil treatment) were fixed factors. Two-way ANOVA was used to test the interaction between soil origins and soil treatments on plant growth indices and soil properties. Differences in means across soil origins and soil treatments were analyzed with Tukey's HSD test using the R package Agricolae [49]. Survival was measured using the Kaplan-Meier procedure; survival curves were compared statistically using log-rank test (LogranKA package) and Cox-regression (survival package) survival analysis was used to test the interaction between soil origins and soil treatments [50].

Rarefied OTU tables were used to analyze soil microbial community composition and diversity Indices (Shannon $\left(\mathrm{H}^{\prime}\right)$ and Simpson (D)) and number of OTUs observed. The effects of soil origin between treatments on $\mathrm{H}^{\prime}, \mathrm{D}$, and number of OTUs observed were non-parametrically determined (Kruskal-Wallis test). To test the effect of soil origins and soil treatments on microbial communities, PerMANOVA (1000 permutations) was performed by using the Adonis function in the vegan package of R [51]. Non-metric multidimensional scaling based on Bray-Curtis dissimilarity was used to visualize the results, and the relationships between soil properties, and microbial communities were tested using the envfit function in the vegan package of $R$ [51].

\section{Results}

\subsection{Soil Microbial Community}

\subsubsection{Soil Bacterial Community Composition, Abundance, and Relationship with Soil Properties}

Acidobacteria, Actinobacteria, Crenarchaeota, Nitrospirae and Proteobacteria were the most abundant bacterial phyla in the original forest soils (Figure 3a). Whereas, Actinobacteria, Gammatimonadetes, and Proteobacteria were the most dominant bacterial phyla in the DL soil (Figure 3a). For both plant species, the relative abundance of Proteobacteria was higher in sterilized soils ( $47 \%$ and $53 \%$, respectively) than in non-sterilized ones ( $28 \%$ and $29 \%$, respectively); in contrast, the relative abundance of Actinobacteria was higher in non-sterilized soils (Figure 3b,c). Also, in non-sterilized soils, the abundance of Acidobacteria was higher in DL, CM, and JP for Olea seedlings (Figure 3b) and in all soil origins for Albizia seedlings (Figure 3c).

The values of indices $\left(\mathrm{H}^{\prime}\right.$ and $\left.\mathrm{D}\right)$, and the number of OTUs observed for bacteria under Olea (Figure 4a,e,i), and Albizia (Figure 4c,g,k) seedlings were significantly higher in non-sterilized than in sterilized soils. The bacterial community significantly varied among soil origins (PerMANOVA; $\mathrm{F}=13.63, p<0.001)$ and between sterilize versus non-sterilize soil treatments $(\mathrm{F}=3.27, p<0.001)$ and seedling types $(\mathrm{F}=16.79, p<0.001)$. The relative abundance of Acidobacteria, Actinobacteria, and Nitrospirae was significantly correlated with bacterial community in non-sterilized forest soils $\left(\mathrm{r}^{2}=0.63, \mathrm{r}^{2}=0.77, \mathrm{r}^{2}=0.79\right.$, respectively; $\left.p<0.001\right)$. Proteobacteria were strongly correlated with bacterial community in sterilized soils $\left(\mathrm{r}^{2}=0.63, p<0.001\right)$, in particular for the forest soils; for the DL soil, the bacterial communities were less related to Acidobacteria, Nitrospirae, and Proteobacteria. In addition, the bacterial communities of DL were grouped in a separate cluster distant from the forest soils (Figure 5a). Among different soil properties, soil $\mathrm{pH}$ was strongly correlated $\left(\mathrm{r}^{2}=0.6, p<0.001\right)$ with the bacterial community (Figure 5a), whereas SOC, TN, the $\mathrm{C} / \mathrm{N}$ ratio, and available $\mathrm{P}$ did not show a strong correlation with the bacterial community. 

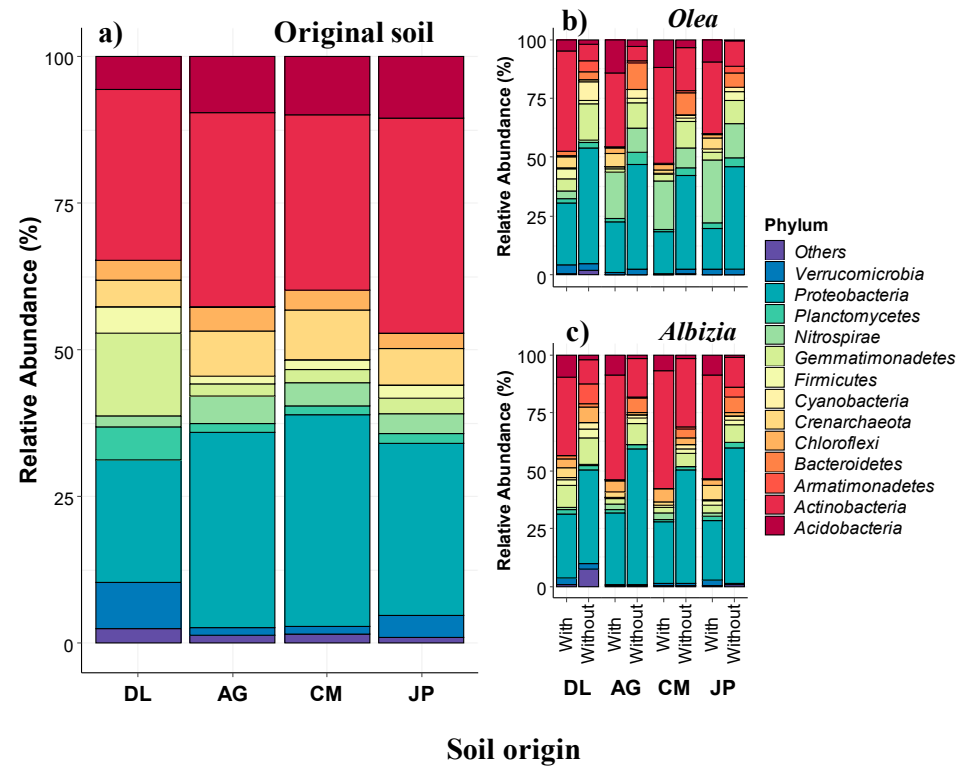

Figure 3. Relative abundances of bacteria at the phylum level in the soil samples; before GH experiment (a) (original soil), and after GH experiment for Olea (b) and Albizia (c) seedlings with treatment (non-sterilized soil) and without treatment (sterilized soil). The values shown are means ( $\mathrm{n}=3$ for soil before GH experiment and $\mathrm{n}=8$ for soil after GH experiment). DL, AG, CM, and JP represent degraded land, Albizia gummifera, Croton macrostachyus, and Juniperus procera, respectively.
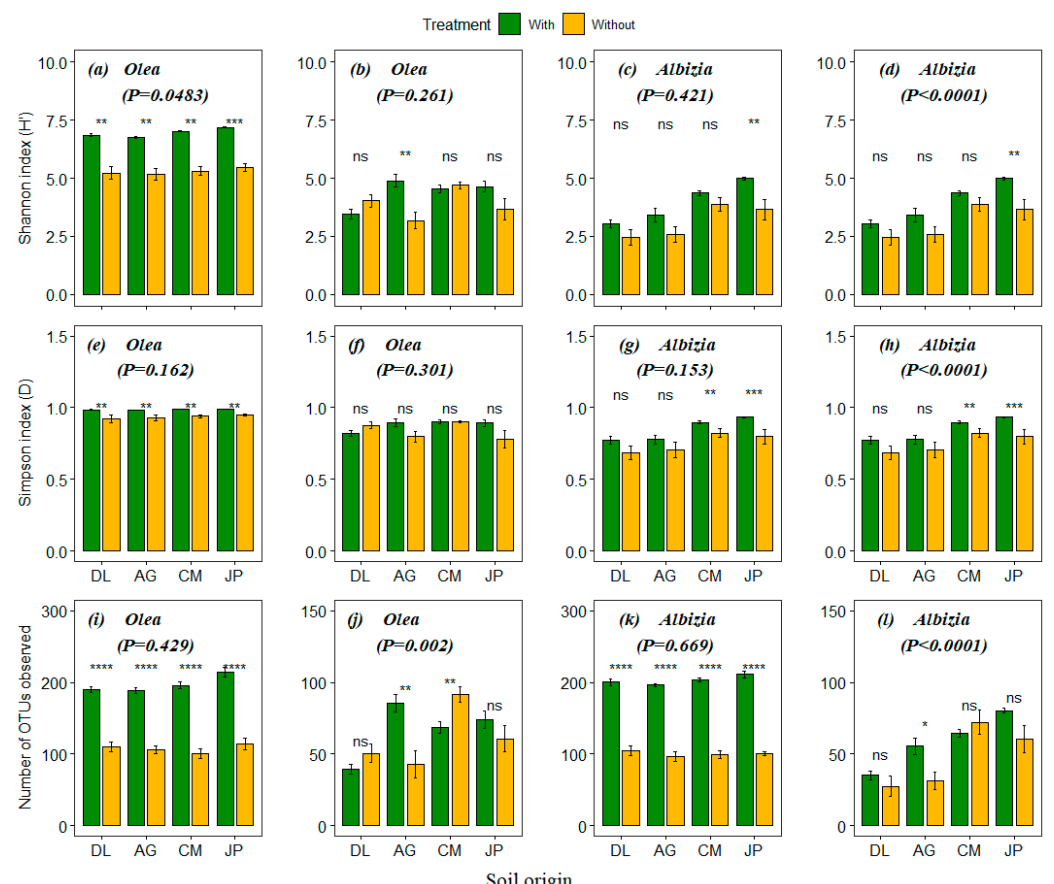

Figure 4. Shannon $\left(\mathrm{H}^{\prime}\right)$ index $(\mathbf{a}-\mathbf{d})$, Simpson (D) index $(\mathbf{e}-\mathbf{h})$, and number of OTUs $(\mathbf{i}-\mathbf{l})$ observed for bacteria (columns 1 and 3) and fungi (columns 2 and 4) for Olea and Albizia seedlings with (non-sterilized; green bars) and without (sterilized; yellow bars) treatments. DL, AG, CM, and JP stand for different soil origins from degraded land, or from beneath Albizia gummifera, Croton macrostachyus, and Juniperus procera, respectively. Asterisks indicate statistically significant differences between seedlings in non-sterilized (with treatment) and sterilized (without treatment) soil ( $p \leq 0.05$; ${ }^{* *} p \leq$ $0.01 ;{ }^{* * *} p \leq 0.001{ }^{* * * *} p \leq 0.0001$; and ns, not significant) and $p$-value (Kruskal test among soil origins). Values are shown as mean \pm standard error $(n=8)$. 

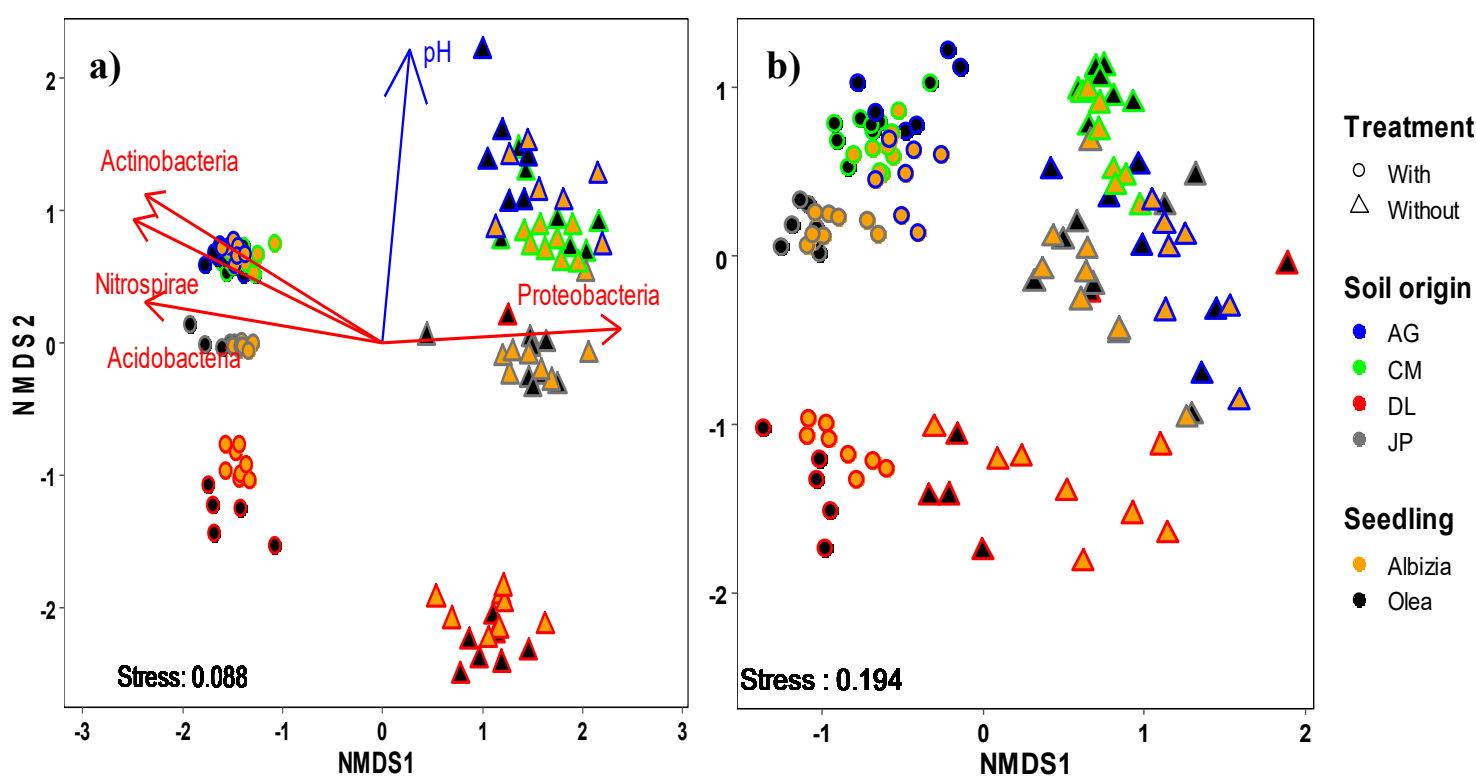

Figure 5. Non-metric multidimensional scaling based on Bray-Curtis dissimilarities for the (a) bacterial and (b) fungal communities. Shapes of symbols represent soil treatments, colors of symbols represent soil origins (AG, CM, DL, and JP), and fills with the symbols represent Albizia and Olea seedlings. Arrows indicate significant correlations and the lengths of arrows are relative to the strength of the correlation. DL, AG, CM, and JP stands for soil from degraded land or from beneath Albizia gummifera, Croton macrostachyus, Juniperus procera, respectively.

\subsubsection{Soil Fungal Community Composition, Abundance, and Relationship with Soil Properties}

In the soils before GH experiment, Ascomycota (48\%, 70\%, 72\%, and 68\%) and Basidiomycota $(21 \%$, $16 \%, 11 \%$ and $17 \%$ ) were the most abundant fungi phyla, respectively in DL, AG, CM, and JP (Figure 6a). In addition, a relatively higher abundance of Glomeromycota was found in DL soils. Similarly, for soils after GH experiment, Ascomycota and Basidiomycota were the most abundant fungal phyla under Olea and Albizia seedlings (Figure 6b,c). Ascomycota had a higher relative abundance for Olea seedlings in non-sterilized ( $89 \%, 93 \%, 93 \%$, and $76 \%$ ) than in sterilized $(81 \%, 80 \%, 78 \%$, and $78 \%$ ) DL, AG, CM, and JP soils, respectively. However, the abundance of Basidiomycota was relatively higher in sterilized $(11 \%, 14 \%$, and $18 \%)$ than non-sterilized $(3 \%, 5 \%$, and $5 \%)$ of DL, AG, and CM soils, respectively (Figure 4b). The relative abundance of Ascomycota under Albizia seedlings in DL, AG, CM, and JP were $80 \%, 88 \%, 80 \%$, and $83 \%$; and $62 \%, 62 \%, 75 \%$, and $74 \%$ for seedlings in non-sterilized and sterilized soils, respectively (Figure 6c).

Significant differences in $\mathrm{H}^{\prime}$ for the fungal community were found between soil treatments for Olea (Figure 4b) and Albizia seedlings (Figure 4d) in AG and JP soils, respectively. In addition, significant variation in D was found in CM and JP soils for Albizia seedlings (Figure 4h) between non-sterilized and sterilized soil. The number of OTUs observed for fungi were significantly higher under seedlings with non-sterilized AG soil for both Olea and Albizia (Figure 4j,1) than with sterilized soil, but the case was the opposite for CM soil for Olea (Figure 4j). However, the DL soil had significantly fewer OTUs for fungi than the forest soils (AG, CM, and JP).

PerMANOVA results indicated that the fungal community significantly differed among soil origins $(\mathrm{F}=12.71, p<0.001)$ and between soil treatments $(\mathrm{F}=2.70, p<0.001)$ and seedling types ( $\mathrm{F}=8.40, p<0.001)$. The relative abundance of Ascomycota and Basidiomycota had a weak correlation $\left(\mathrm{r}^{2}<0.5, p<0.001\right.$ with the fungal community. There was no correlation between the soil properties $(\mathrm{pH}, \mathrm{SOC}, \mathrm{TN}, \mathrm{C} / \mathrm{N}$ ratio, and available $\mathrm{P}$ ) and the fungal community (Figure $5 \mathrm{~b}$ ). 


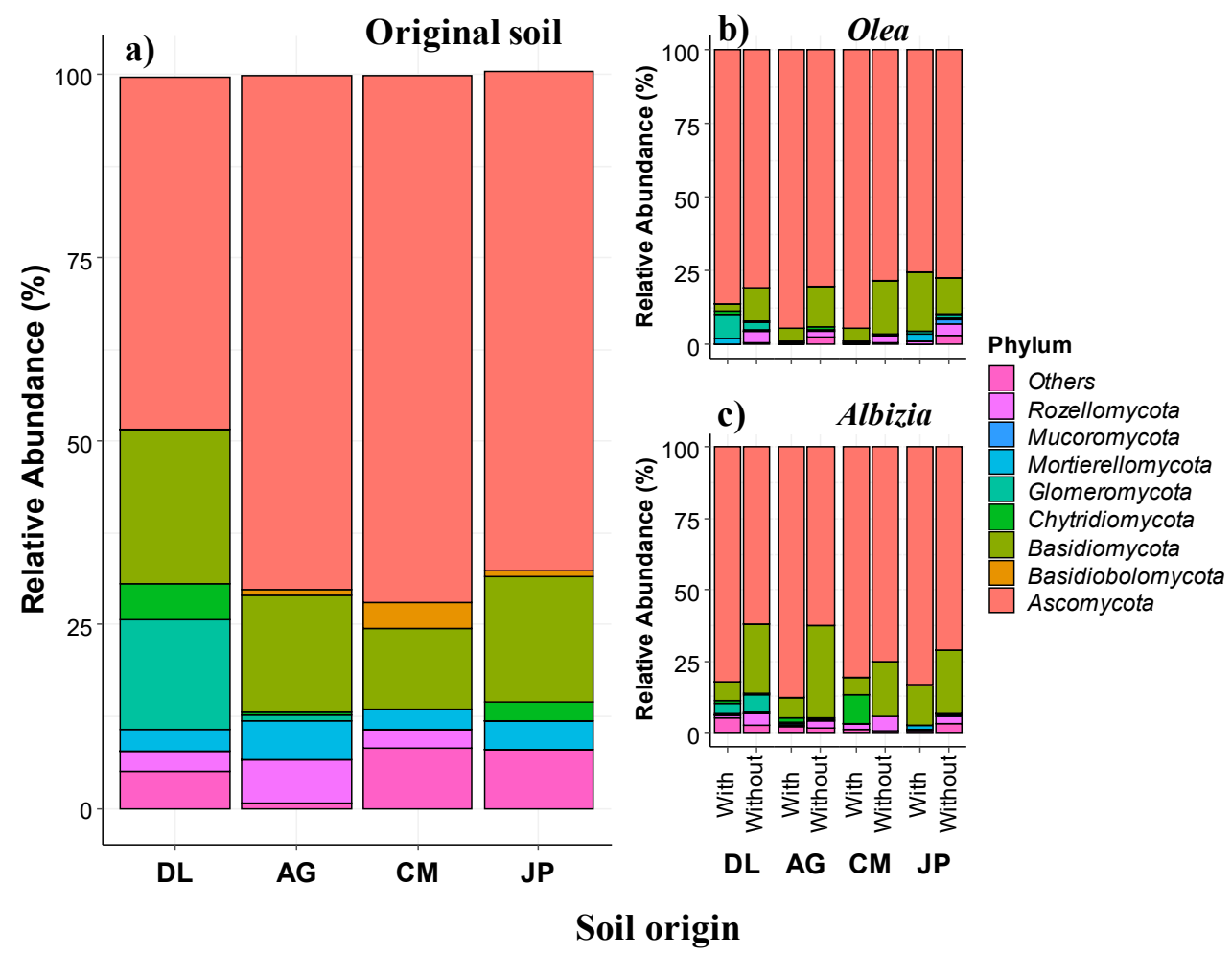

Figure 6. Relative abundances of fungi at the phylum level in the soil samples: before GH experiment (a) (original soil), and after GH experiment for Olea (b) and Albizia (c) seedlings with treatment (non-sterilized soil) and without treatment (sterilized soil). The values shown are means ( $\mathrm{n}=3$ for soil before GH experiment and $\mathrm{n}=8$ for soil after GH experiment). DL, AG, CM, and JP represent degraded land, Albizia gummifera, Croton macrostachyus, and Juniperus procera, respectively.

\subsection{Effect of Soil Origins and Soil Treatments on Plant Growth and Survival}

The factors including species, soil origins and soil treatments were all considered in the model for analysis of variance (Table S1). The results indicated that most of plant characteristics and soil properties are related with species, soil origins, soil treatments, and their interactions. The results of the three-way ANOVA demonstrated that species, and the interactions between species and soil origins, soil treatments and soil origins, and species, soil treatments and soil origins were the most important factors affecting plant characteristics excluding the R/S ratio (Table S1). The soil origins also significantly affected plant characteristics $(p<0.05$; Table S1). Except for root mass, soil treatments substantially influenced plant characteristics. However, the interaction of species and soil treatments significantly determined survival rate, shoot and total mass of plants $(p<0.05$; Table S1).

After separating per species, the two-way ANOVA indicated that soil treatments, soil origins, and their interaction had a significant effect on plant height, RCD, shoot mass, total mass, and survival rate of Olea and Albizia seedlings (Table S1). Olea seedlings grown in non-sterilized AG, CM, and JP soils showed significantly higher plant height (Figure 7a), total mass (Figure 7i), RCD (Figure S4a), and shoot mass (Figure S4c), than seedlings grown in sterilized soils. For the same plant characteristics, there was no significant difference between sterilized and non-sterilized DL soils (Figure 7a,c,e). Root mass did not vary between soil treatments, except in CM soil, where it was significantly increased more than double in non-sterilized soil (Figure S4e). In contrast, the R/S ratio for Olea seedlings grown in sterilized AG, CM, and JP soils was significantly higher than seedlings grown in the non-sterilized soils (Figure 7e). For Albizia seedlings, the RCD (Figure S4b) and shoot mass (Figure S4d) significantly varied in DL and CM non-sterilized soils than seedlings in sterilized soils. The shoot mass of Albizia seedlings were significantly higher for both treatments of AG and non-sterilized CM soil than the other 
treatments (Figure S4d). Root mass (Figure S4f) was significantly higher in sterilized AG and JP soils, significantly lower in CM soil, and was not significantly different in DL soil.
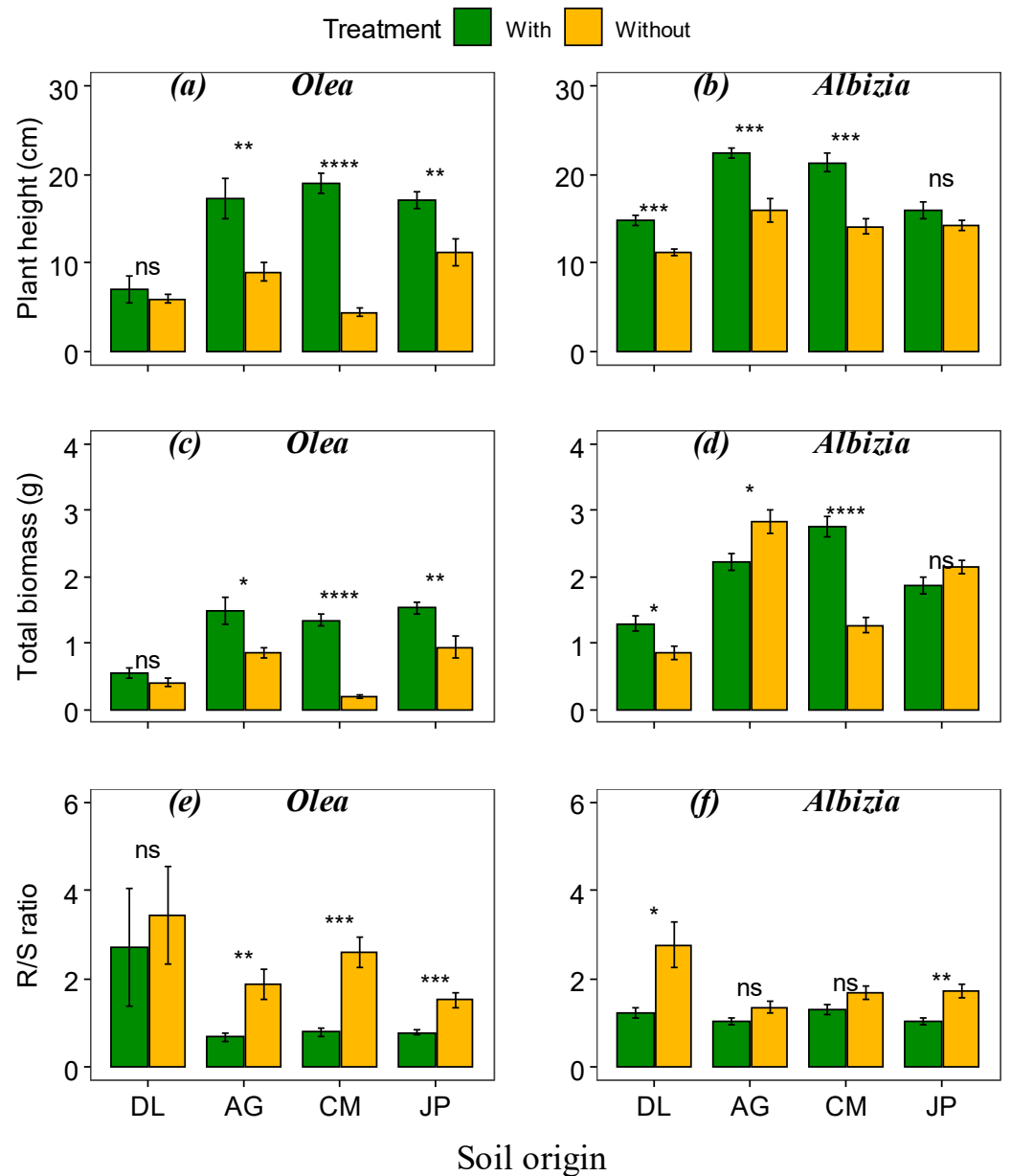

Figure 7. Effects of soil from different origins on plant height $(\mathbf{a}, \mathbf{b})$, total biomass (c,d), and root to shoot (R/S) ratio (e,f) of Olea and Albizia seedlings, respectively, with treatment (non-sterilized soil) and without treatment (sterilized soil). DL, AG, CM, and JP stand for soil origins from degraded land, or from beneath Albizia gummifera, Croton macrostachyus, and Juniperus procera, respectively. Asterisks indicate statistically significant differences between seedlings with treatment (in non-sterilized soil) and without treatment (in sterilized soil): ${ }^{*} p \leq 0.05 ;{ }^{* *} p \leq 0.01 ;{ }^{* * *} p \leq 0.001 ;{ }^{* * * *} p \leq 0.0001$; and ns, not significant). Values are mean \pm standard error $(n=8)$.

Survival analysis showed no significant differences in survival rate between Olea seedlings with non-sterilized and sterilized soil $\left(\chi^{2}(1)=3.32, p=0.061\right)$, although the survival rate for seedlings with sterilized soil (97\%) was slightly higher than for those in non-sterilized soil (95\%). Survival rate significantly differed among soil origins for Olea seedlings $\left(\chi^{2}(3)=17.64, p<0.001\right)$. Survival of Albizia seedlings was significantly affected by the soil treatments (Table S1) and soil origins (Table S1). Albizia seedlings survived better with the sterilized treatment (100\%) than with the non-sterilized treatment $(97 \%)$. The survival rate in AG, CM, and JP soils was found to be similar and significantly higher than in DL (92\%). The interaction between soil treatments and soil origins had no significant effect on survival of either Olea or Albizia seedlings (Table S1; $\chi^{2}(3)=3.32, p=0.06$ and $\chi^{2}(3)=6.03$, $p=0.42$, respectively). 


\subsection{Soil Chemical and Physical Properties}

Soil $\mathrm{pH}, \mathrm{TN}$ content and $\mathrm{C} / \mathrm{N}$ ratio were strongly dependent on species $(p<0.05)$. Soil origins $(p<0.05)$ also influenced $\mathrm{pH}, \mathrm{SOC}, \mathrm{TN}$ and available $\mathrm{P}$, but not the $\mathrm{C} / \mathrm{N}$ ratio. Except for available $\mathrm{P}$, soil treatments did not affect soil characteristics. In addition, the interaction between species and soil origins, and species, soil origin and soil treatments affected SOC and TN contents $(p<0.05$; Table S1). Available $\mathrm{P}$ and SOC content were also dependent on the interaction of species and soil treatments, and soil origins and soil treatments, respectively.

Significant differences $(p<0.05)$ in soil $\mathrm{pH}$ between original soil and the soils after the GH experiment were observed for both species and soil treatments in AG and JP soils (Tables 1 and 2). SOC content for Olea and Albizia seedlings varied significantly between before (original soil) and after GH experiments in both soil treatments of AG and DL, respectively. Whereas SOC content only varied significantly in DL (sterilized) and JP (non-sterilized) soils, respectively for Olea and Albizia seedlings. The TN contents in DL soil for both species and soil treatments were significantly different between original soil and the soils after the GH experiments. There was significant variation in the $\mathrm{C} / \mathrm{N}$ ratio of DL (sterilized) and AG in both soil treatments between original soil and the soils after the GH experiments. However, available P only significantly varied in non-sterilized AG soil of Albizia seedlings.

Table 1. Major soil characteristics of degraded land and church forest soils $(n=3)$.

\begin{tabular}{|c|c|c|c|c|c|c|c|c|c|c|}
\hline Soil & $\mathrm{pH}$ & MC (\%) & SOC (\%) & TN (\%) & $\mathrm{C} / \mathrm{N}$ & $\begin{array}{c}\text { Avail. P } \\
\left(\mathrm{mg} \mathrm{kg}^{-1}\right)\end{array}$ & Sand (\%) & Silt (\%) & Clay (\%) & $\begin{array}{l}\text { Texture Class } \\
\text { (USDA) }^{\mathrm{a}}\end{array}$ \\
\hline DL & $\begin{array}{c}5.6 \\
(0.2)^{\mathrm{b}}\end{array}$ & $\begin{array}{l}11.7 \\
(1.1)^{\mathrm{c}}\end{array}$ & $\begin{array}{l}6.0 \\
(0.2)^{b}\end{array}$ & $\begin{array}{c}0.8 \\
(0.1)^{\mathrm{b}}\end{array}$ & $\begin{array}{l}10.2 \\
(0.3)^{b}\end{array}$ & $\begin{array}{l}29.4 \\
(1.1)^{b}\end{array}$ & 68 & 11 & 21 & Sandy clay loam \\
\hline AG & $\begin{array}{c}6.1 \\
(0.1)^{\mathrm{ab}}\end{array}$ & $\begin{array}{l}26.7 \\
(2.0)^{a}\end{array}$ & $\begin{array}{c}12.0 \\
(1.2)^{\mathrm{a}}\end{array}$ & $\begin{array}{c}1.0 \\
(0.1)^{\mathrm{a}}\end{array}$ & $\begin{array}{c}11.8 \\
(1.8)^{\mathrm{a}}\end{array}$ & $\begin{array}{c}88.2 \\
(5.9)^{\mathrm{a}}\end{array}$ & 68 & 12 & 20 & Sandy loam \\
\hline $\mathrm{CM}$ & $\begin{array}{c}6.5 \\
(0.2)^{\mathrm{ab}}\end{array}$ & $\begin{array}{c}23.3 \\
(1.5)^{\mathrm{ab}}\end{array}$ & $\begin{array}{c}8.1 \\
(1.1)^{\mathrm{ab}}\end{array}$ & $\begin{array}{c}0.7 \\
(0.1)^{\mathrm{b}}\end{array}$ & $\begin{array}{c}11.3 \\
(0.4)^{\mathrm{a}}\end{array}$ & $\begin{array}{c}39.8 \\
(4.2)^{b}\end{array}$ & 64 & 17 & 19 & Sandy loam \\
\hline $\mathrm{JP}$ & $\begin{array}{c}7.0 \\
(0.3)^{\mathrm{a}}\end{array}$ & $\begin{array}{c}17.0 \\
(1.6)^{b c}\end{array}$ & $\begin{array}{c}8.7 \\
(0.4)^{\mathrm{ab}}\end{array}$ & $\begin{array}{c}0.8 \\
(0.1)^{\mathrm{b}}\end{array}$ & $\begin{array}{l}10.8 \\
(0.1)^{b}\end{array}$ & $\begin{array}{c}76.3 \\
(5.1)^{\mathrm{a}}\end{array}$ & 67 & 14 & 19 & Sandy loam \\
\hline
\end{tabular}

Different lowercase letters indicate significant differences among soil origins [values are mean ( \pm standard error)]; Tukey HSD, $p<0.05, \mathrm{n}=3$. Soil in degraded land (DL) and under mature trees of Albizia gummifera (AG), Croton macrostachyus (CM), Juniperus procera (JP). MC, moisture content at sampling. SOC, soil organic carbon. TN, total nitrogen. C/N, carbon/nitrogen ratio. Avail.P, available phosphorus. ${ }^{a}$ Soil texture class is according to [52].

Table 2. Soil characteristics of Olea and Albizia seedlings inoculated with and without four different soil origins at the end of the 5 months experiment (DL, soil from degraded land; AG/CM/JP, soil from beneath A. gummifera, C. macrostachyus, and J. procera, respectively).

\begin{tabular}{|c|c|c|c|c|c|c|c|c|c|c|c|c|c|}
\hline \multirow{2}{*}{ Species } & \multirow{2}{*}{ Soil Origin } & \multicolumn{2}{|c|}{$\mathrm{pH}$} & \multicolumn{2}{|c|}{ SOC (\%) } & \multicolumn{2}{|c|}{ TN (\%) } & \multicolumn{2}{|c|}{$\mathrm{C} / \mathrm{N}$} & \multicolumn{2}{|c|}{ Avail.P (mg kg-1) } & \multicolumn{2}{|c|}{ SAS (SI, $\left.\mathrm{cm}^{-1}\right)$} \\
\hline & & with & without & with & without & with & without & with & without & with & without & with & without \\
\hline \multirow{12}{*}{ Olea } & \multirow{3}{*}{ DL } & 5.9 & 5.9 & 4.5 & 7.9 & 0.4 & 0.7 & 11 & 11 & 28.4 & 30.7 & 0.02 & 0.01 \\
\hline & & $\begin{array}{l}(0.1) \\
\mathrm{cA}\end{array}$ & $(0.1)^{\mathrm{cA}}$ & -1.3 & -0.8 & -0.1 & -0.1 & -0.2 & -0.1 & $(0.6)^{d}$ & $(0.4)^{\mathrm{d}}$ & $(0.0)^{c}$ & $(0.0)^{c}$ \\
\hline & & $\mathrm{ns}$ & $\mathrm{ns}$ & ns & $*$ & * & * & ns & ns & ns & ns & & \\
\hline & \multirow{3}{*}{ AG } & 6.7 & 7.2 & 6.7 & 10.1 & 0.6 & 0.92 & 11.1 & 11.4 & 88 & 86.1 & 0.05 & 0.04 \\
\hline & & $\underset{\mathrm{aB}}{(0.1)}$ & $(0.1)^{\mathrm{aA}}$ & -1.8 & -1.5 & -0.2 & -0.1 & -0.5 & -0.2 & $(3.3)^{\mathrm{a}}$ & $(4.7)^{\mathrm{a}}$ & $(0.0)^{\mathrm{aA}}$ & $(0.0)^{\mathrm{aB}}$ \\
\hline & & * & * & * & * & * & ns & ns & ns & ns & ns & & \\
\hline & \multirow{3}{*}{$\mathrm{CM}$} & 6.6 & 6.6 & 6.3 & 5.7 & 0.6 & 0.5 & & 10.9 & 42.2 & 42.5 & 0.04 & 0.03 \\
\hline & & $\underset{\mathrm{aA}}{(0.1)}$ & $(0.1)^{\mathrm{aA}}$ & -1.4 & -1.5 & -0.1 & -0.1 & -0.2 & -0.2 & $(0.7)^{\mathrm{c}}$ & $(0.7)^{\mathrm{c}}$ & $(0.0)^{\mathrm{bA}}$ & $(0.0)^{\mathrm{bB}}$ \\
\hline & & ns & ns & ns & ns & ns & ns & ns & ns & ns & ns & & \\
\hline & \multirow{3}{*}{ JP } & 6.3 & 5.9 & 8.3 & 6.8 & 0.7 & 0.62 & 11.3 & 10.9 & 77.9 & 74.8 & 0.04 & 0.03 \\
\hline & & $\begin{array}{l}(0.1) \\
\mathrm{bA}\end{array}$ & $(0.1)^{\mathrm{bB}}$ & -1.7 & -0.7 & -0.1 & -0.1 & -0.1 & -0.1 & $(2.2)^{b}$ & $(2.0)^{b}$ & $(0.0)^{\mathrm{b}}$ & $(0.0)^{\mathrm{b}}$ \\
\hline & & * & * & ns & ns & ns & ns & ns & ns & ns & ns & & \\
\hline
\end{tabular}


Table 2. Cont.

\begin{tabular}{|c|c|c|c|c|c|c|c|c|c|c|c|c|c|}
\hline \multirow{2}{*}{ Species } & \multirow{2}{*}{ Soil Origin } & \multicolumn{2}{|c|}{$\mathrm{pH}$} & \multicolumn{2}{|c|}{ SOC (\%) } & \multicolumn{2}{|c|}{ TN (\%) } & \multicolumn{2}{|c|}{$\mathrm{C} / \mathrm{N}$} & \multicolumn{2}{|c|}{ Avail.P (mg kg ${ }^{-1}$ ) } & \multicolumn{2}{|c|}{ SAS (SI, $\left.\mathrm{cm}^{-1}\right)$} \\
\hline & & with & without & with & without & with & without & with & without & with & without & with & without \\
\hline \multirow{12}{*}{ Albizia } & \multirow{3}{*}{ DL } & 5.6 & 5.9 & 3.9 & 3.7 & 0.4 & 0.3 & 10.1 & 11.4 & 27.3 & 28.6 & 0.02 & 0.01 \\
\hline & & $\underset{\mathrm{dB}}{(0.1)}$ & $(0.0)^{\mathrm{dA}}$ & $\underset{\mathrm{d}}{(0.0)}$ & $(0.0)^{\mathrm{d}}$ & $\underset{\mathrm{d}}{(0.0)}$ & $(0.0)^{\mathrm{c}}$ & $\begin{array}{c}(0.1) \\
a\end{array}$ & $(0.2)^{\mathrm{a}}$ & $(0.4)^{\mathrm{dB}}$ & $(0.6)^{\mathrm{dA}}$ & $(0.0)^{\mathrm{d}}$ & $(0.0)^{c}$ \\
\hline & & ns & ns & * & * & * & * & ns & * & $\mathrm{ns}$ & ns & & \\
\hline & \multirow{3}{*}{ AG } & 7 & 7.4 & 12.1 & 11.9 & 1 & 1 & 11.6 & 11.6 & 74.1 & 86.9 & 0.05 & 0.04 \\
\hline & & $\underset{\mathrm{aB}}{(0.1)}$ & $(0.0)^{\mathrm{aA}}$ & $\frac{(0.2)}{a}$ & $(0.7)^{\mathrm{a}}$ & $\begin{array}{c}(0.0) \\
a\end{array}$ & $(0.1)^{\mathrm{a}}$ & $\begin{array}{c}(0.1) \\
a\end{array}$ & $(0.1)^{\mathrm{a}}$ & $(2.0)^{\mathrm{bB}}$ & $(3.9)^{\mathrm{bA}}$ & $(0.0)^{\mathrm{aA}}$ & $(0.0)^{\mathrm{aB}}$ \\
\hline & & * & * & $\mathrm{ns}$ & $\mathrm{ns}$ & ns & ns & * & * & * & ns & & \\
\hline & \multirow{3}{*}{$\mathrm{CM}$} & 6.5 & 6.6 & 8.3 & 8.6 & 0.8 & 0.8 & 10.7 & 10.8 & 34.5 & 47.3 & 0.04 & 0.04 \\
\hline & & $\underset{\mathrm{bA}}{(0.0)}$ & $(0.1)^{\mathrm{bA}}$ & $\underset{\mathrm{b}}{(0.1)}$ & $(0.4)^{\mathrm{b}}$ & $\underset{\mathrm{b}}{(0.0)}$ & $(0.0)^{\mathrm{b}}$ & $(0.1)$ & $(0.1)^{b}$ & $(0.8)^{\mathrm{c}}$ & $(1.1)^{\mathrm{c}}$ & $(0.0)^{\mathrm{b}}$ & $(0.0)^{\mathrm{a}}$ \\
\hline & & ns & ns & ns & ns & ns & ns & ns & ns & ns & ns & & \\
\hline & \multirow{3}{*}{ JP } & 6 & 6.3 & 7.3 & 7.7 & 0.7 & 0.7 & 10.6 & 10.7 & 74.2 & 94.8 & 0.03 & 0.03 \\
\hline & & $\begin{array}{c}(0.0) \\
\mathrm{CB}\end{array}$ & $(0.0)^{\mathrm{cA}}$ & $\underset{c}{(0.1)}$ & $(0.1)^{\mathrm{c}}$ & $\begin{array}{c}(0.0) \\
\mathrm{c}\end{array}$ & $(0.0)^{\mathrm{b}}$ & $\underset{\mathrm{b}}{(0.1)}$ & $(0.0)^{\mathrm{b}}$ & $(3.7)^{\mathrm{aB}}$ & $(1.5)^{\mathrm{aA}}$ & $(0.0)^{\mathrm{c}}$ & $(0.0)^{\mathrm{b}}$ \\
\hline & & * & * & * & ns & ns & ns & ns & ns & $\mathrm{ns}$ & * & & \\
\hline
\end{tabular}

Different superscript lowercase letters indicate significant differences among soil origins for each species; different superscript uppercase letters indicate significant differences between soil treatments (Tukey HSD, $p<0.05, \mathrm{n}=8$ ) and asterisks indicate statistically significant differences between before (Table 1) and after GH experiments in the same soil origin $(* p \leq 0.05$; and ns, not significant). Values are mean ( \pm standard error).

For Albizia seedlings, soil pH was significantly affected by soil treatments and soil origins and their interactions, whereas for Olea seedlings, soil origins and its interaction with soil treatments were significant (Table S1). Soil pH for Olea seedlings with non-sterilized JP soil was significantly higher than for seedlings in sterilized soil, whereas with AG soil, the opposite trend was observed (Table 2). Except for $\mathrm{CM}$ soil, there was a significant difference in $\mathrm{pH}$ between non-sterilized and sterilized soil for Albizia seedlings, i.e., in DL, AG, and JP soils, $\mathrm{pH}$ was significantly higher for seedlings in sterilized soil (Table 2). For both Olea and Albizia seedlings, regardless of soil treatments, pH of DL was significantly lower than AG and CM but was comparable with JP (Table 2).

Generally, SOC, TN, C/N ratio, and available $\mathrm{P}$ for Olea seedlings were not significantly affected by soil treatments, soil origins, and their interaction. SOC, TN, and $\mathrm{C} / \mathrm{N}$ ratio for Olea seedlings did not significantly vary between soil origins (Table S1). Sterilized AG soil had a higher SOC $(10.10 \%)$ and TN $(0.92 \%)$ contents, whereas the lowest SOC $(4.48 \%)$ and TN $(0.40 \%)$ contents were found in non-sterilized DL soil (Table 2). The highest (11.40) and the lowest (10.90) C/N ratios for Olea were measured in CM sterilized and non-sterilized soils, respectively (Table 2).

Soil available $\mathrm{P}$ significantly differed among soil origins for Olea seedlings (Table S1). The non-sterilized AG soil had a significantly higher available $\mathrm{P}\left(88.00 \mathrm{mg} \mathrm{kg}^{-1}\right)$ than the others. The lowest content of available P $\left(28.40 \mathrm{mg} \mathrm{kg}^{-1}\right)$ was found in DL non-sterilized soil for Olea. Available $P$ in the forest soils was highest in AG followed by JP then CM (Table 2). In contrast to Olea seedlings, SOC, TN, C/N, and available P for Albizia seedlings significantly varied among soil origins, with SOC and TN in particular being significantly influenced by soil origins.

However, except for available $\mathrm{P}$ content and $\mathrm{C} / \mathrm{N}$ ratio, other soil characteristics did not significantly differ between sterilized and non-sterilized soil (Table 2). SAS was numerically higher in non-sterilized than in sterilized soil for both Olea and Albizia seedlings (Table 2), significantly so for AG and CM soil with Olea seedlings, and for AG soil with Albizia. Regardless of soil treatments, for both Olea and Albizia seedlings, SAS for all of the forest soils (AG, CM, and JP) was significantly higher than for DL soil (Table 2).

\section{Discussion}

The soil from the four origins in this study caused significant variation in plant characteristics (Figure 7). Olea seedlings with non-sterilized soil of Albizia gummifera, Croton macrostachyus, and Juniperus procera showed higher plant growth compared to seedlings with sterilized soil. Plant characteristics of Albizia seedlings were consistently affected by non-sterilized soil from Croton macrostachyus, whereas for other soil origins the effect was not consistent. Olea and Albizia 
are species that co-exist in dry Afromontane forest of Ethiopia [29] and have arbuscular mycorrhizal associations [53]. Our results agree with other studies that have shown that inoculation with the appropriate microbes can significantly modify or improve seedling growth [53], pathogen resistance [12], and biomass production [54]. Conversely, seedlings of both species in non-sterilized Croton macrostachyus soil consistently varied in plant growth (Figure 7). This may be linked to the abundance of Actinobacteria and Nitrospirae for seedlings in non-sterilized soil, which is strongly related to the bacterial community of forest soils in particular with Croton macrostachyus soil (Figures 3 and 6). Several reports have indicated that members of the phylum Actinobacteria are involved in organic matter decomposition, plant growth promotion, and soil pathogen control [54]. Also, Nitrospirae is one of the phyla whose members are involved in soil nitrification [55]; therefore, their abundance in soil may influence the availability of soil nitrogen [56]. However, the phylum Proteobacteria was highly correlated with seedlings in sterilized soil. Furthermore, relatively high soil $\mathrm{pH}$ was observed for seedlings in non-sterilized soils (Table 2 and Figure 5). Studies have reported that the abundance of Proteobacteria is positively correlated to soil $\mathrm{pH}$ [56].

Likewise, Ascomycota and Basidiomycota are found to be the most abundant fungi phyla in forest soils. Ascomycota is saprophytic in the soil, which had high resistance and better environmental adaptability [57]. It can also decompose most plant and animal residue into nutrients that can be available for plants [58]. Similarly, Basidiomycota plays a key role in the decomposition of organic matter in the soil, such as lignins, resins, tannin, and other compounds which might affect soil properties [59]. However, in this study, the abundance of Ascomycota and Basidiomycota was slightly influenced by species type (Figure 4). Several studies have reported that plant species type can influence the structure of the soil microbial community by producing a different amount of organic matter, altering the soil moisture and nutrition status [60-62]. Moreover, the quality and quantity of organic compounds released by plant roots such as carbohydrates, amino acids, organic acids, and enzymes can also influence the soil microbial community by exerting stimulatory and/or inhibiting effects $[63,64]$. In this study, lower forest soil TN $(0.07 \%)$ and P $\left(39.84 \mathrm{mg} \mathrm{kg}^{-1}\right)$ contents were found in Croton macrostachyus soil. According to Wubet et al. [53], native tree species of the dry Afromontane forest in Ethiopia have mycorrhizal associations, which are effective tools when the soil nutrients (i.e., $\mathrm{N}$ and $\mathrm{P}$ ) are limited [53]. However, fungal abundance in the experimental soil was low, and fungal communities did not correlate with the soil properties, and had lower diversity, evenness, and number of operational taxonomic units than bacterial communities. This result is in line with other studies $[65,66]$. Thus, when a difference in $\mathrm{pH}$ range preference for optimum growth pertains, soil $\mathrm{pH}$ is often a factor exerting more control over the abundance of the bacterial community than the fungal community. Additionally, the beneficial effect of soil from beneath Croton macrostachyus on the regeneration of Olea seedlings [67] has been reported in the highlands of Ethiopia.

As expected, Olea seedlings in degraded land soil did not vary in size among soil treatments (Figure 7). This could be due to the low level of soil microbial diversity and abundance, which are common soil characteristics of degraded land [68]. Soil microbes are widely known to enhance plant growth, increase efficiency of nutrient uptake, and facilitate establishment and competitive ability of seedlings. Moreover, in the present study, degraded land soil had lower fungal diversity and number of operational taxonomic units than forest soil. Correspondingly, SOC, TN, available $\mathrm{P}$, and moisture content were found at lower levels in degraded land soil than in forest soil (Table 1).

Plant biomass allocation strategy is species-dependent and varies with environmental factors [68]. Studies have shown that resource availability controls biomass allocation patterns in plants [69,70], especially for the root to shoot ratio. In the present study, root to shoot ratios for Olea seedlings in Albizia gummifera, Croton macrostachyus and Juniperus procera sterilized soil were higher than in non-sterilized soil. The root to shoot ratio was highest in Olea seedlings, reaching 3.44 in degraded land soil, a value not influenced by soil sterilization. This could be because plants under conditions of low soil nutrients and limited water are obliged to allocate high biomass to their roots to exploit the soil resources more effectively [11,71]. In contrast, low root to shoot ratios were found in seedlings 
in non-sterilized forest soils, which could be because seedlings in non-sterilized soils have greater access to water and nutrients, provided by the microbial association, meaning that seedlings were able to allocate more biomass to the shoot. A similar finding was also reported by Zandavalli et al. [72].

Soil aggregate stability and the process of structure formation are complex, influenced by soil properties (e.g., clay content, organic matter), plant root development, and soil microbial activity [10]. Soil aggregate stability is an indicator of soil aeration and nutrient availability, soil erosion resistance, root penetration, and water regime of the soil [10]. In this study, soil aggregate stability was significantly higher for forest soils than degraded land soil. This result is in agreement with the findings by Delelegn et al. [73], who reported higher soil aggregate stability in natural forest soil than degraded croplands in the highlands of northern Ethiopia. A similar result was also reported by Caravaca et al. [74]. SOC is the main element in soil aggregate formation and is directly related to soil microbial diversity for Caravaca, Lax, and Albaladejo [74]. Loss of SOC results in significant deterioration in soil structure [75], which is a key indicator of soil degradation [75]. Moreover, loss of beneficial soil microbes (mainly fungi and bacteria) significantly affects soil aggregate stability [76]. Furthermore, fungi play a significant role in endorsing the formation of macro-aggregates through their hyphae, which "glue" the micro-aggregates together [77]. However, as mentioned above, the degraded land soil had lower fungal diversity than forest soil. Thus, greater soil aggregate stability under seedlings with non-sterilized Albizia gummifera and Croton macrostachyus soils (Table 2) can be attributed to the higher abundance of beneficial microbes (Figure 4) that facilitate the formation of micro and macro-aggregates [78].

\section{Conclusions}

Higher growth in non-sterilized, than sterilized forest (Albizia gummifera, Croton macrostachyus and Juniperus procera) soil indicates a microbial benefit to seedling growth from forest soil. We also observed higher plant growth in forest soils than in degraded soils mainly due to a higher relative abundance of beneficial bacterial phyla (Acidobacteria, Actinobacteria, and Nitrospirae). Soil pH showed a strong correlation with the abundance of the bacterial community, but no relationship was found between soil properties and fungal communities. Moreover, the effect of soil microbiome was more noticeable on the performance of Olea seedlings grown in the soil from Croton macrostachyus. This suggests that soils from Croton macrostachyus can promote growth and survival of Olea and Albizia seedlings in degraded lands. Overall, the results of this study imply that soils from the remnant church forests could serve as a potential source of soil microbiome for the restoration of degraded lands using native tree species.

Supplementary Materials: The following are available online at http://www.mdpi.com/2071-1050/12/12/4976/s1; Figure S1: Rarefication curve of soil bacteria (a) and fungi (b) communities. Table S1: ANOVA of Olea, Albizia and both seedlings showing results for plant height $(\mathrm{H})$, root collar diameter (RCD), survival rate (SR), shoot mass $(\mathrm{SB})$, root mass $(\mathrm{RB})$, the root to shoot ratio $(\mathrm{R} / \mathrm{S})$, total mass $(\mathrm{TB})$, soil $\mathrm{pH}(\mathrm{pH})$, soil organic carbon (SOC), total nitrogen $(\mathrm{TN})$, carbon to nitrogen ratio $(\mathrm{C} / \mathrm{N})$, and available phosphorus $(\mathrm{P})$. Figure S2: Effect of soil origins on shoot and root growth of Olea seedling at end of the experiment. With treatment (non-sterilized soil) and without treatment (sterilized soil) of DL: Degraded land, AG: Albizia gummifera, CM: Croton macrostachyus and JP: Juniperus procera. Figure S3: Effect of soil origins on shoot and root growth of Albizia seedling at end of the experiment. With (non-sterilized soil) and without (sterilized soil) of DL: Degraded land, AG: Albizia gummifera, CM: Croton macrostachyus and JP: Juniperus procera. Figure S4: Effects of soil from different origins on root collar diameter (RCD) (a, b), shoot mass (c, d), and root mass (e, f), in Olea and Albizia seedlings, respectively, with treatment (non-sterilized soil) and without treatment (sterilized soil). DL, AG, CM, and JP stand for soil origins from degraded land, or from beneath Albizia gummifera, Croton macrostachyus, and Juniperus procera, respectively.

Author Contributions: Conceptualization, G.A. and T.T.; data curation, G.A. and K.E.; validation, A.T. and N.H.; Methodology, G.A., M.W., T.M., A.M. and T.T.; formal analysis, G.A., T.T. and A.M.; investigation, G.A.; resources A.T. and N.H.; writing — original draft preparation, G.A.; writing - review and editing, A.T., E.A., N.H., T.T., M.W., K.E. and D.T.M.; supervision, A.T., N.H., T.T. and M.T.; project administration, A.T., E.A., N.H. and D.T.M.; funding acquisition, A.T., E.A. and N.H. All authors have read and agreed to the published version of the manuscript.

Funding: This research was funded by the Science and Technology Research Partnership for Sustainable Development (grant no. JPMJSA1601), Japan Science and Technology Agency/Japan International Cooperation Agency. 
Acknowledgments: We are grateful to Anteneh Wubet and Agerselam Gualie for the facilitation of our field and laboratory work. We thank Ayele Almaw Fenta and Brihanu Kebede for the watering of seedlings during our absence. We also thank the Arid Land Research Center of Tottori University for providing a convenient research environment and facilities throughout our work.

Conflicts of Interest: The authors declare no conflict of interest.

\section{References}

1. Nkonya, E.; Johnson, T.; Kwon, H.Y.; Kato, E. Economics of land degradation in sub-Saharan Africa. In Economics of Land Degradation and Improvement-A Global Assessment for Sustainable Development; Springer: Cham, Switzerland, 2016; pp. 215-259.

2. Mekuria, W.; Wondie, M.; Amare, T.; Wubet, A.; Feyisa, T.; Yitaferu, B. Restoration of degraded landscapes for ecosystem services in North-Western Ethiopia. Heliyon 2018, 4, e00764. [CrossRef] [PubMed]

3. Nunes, J.S.; Araujo, A.S.F.; Nunes, L.; Lima, L.M.; Carneiro, R.F.V.; Salviano, A.A.C.; Tsai, S.M. Impact of Land Degradation on Soil Microbial Biomass and Activity in Northeast Brazil. Pedosphere 2012, 22, 88-95. [CrossRef]

4. Meshesha, D.T.; Tsunekawa, A.; Tsubo, M.; Ali, S.A.; Haregeweyn, N. Land-use change and its socio-environmental impact in Eastern Ethiopia's highland. Reg. Environ. Chang. 2014, 14, 757-768. [CrossRef]

5. Araujo, A.S.; Borges, C.D.; Tsai, S.M.; Cesarz, S.; Eisenhauer, N. Soil bacterial diversity in degraded and restored lands of Northeast Brazil. Antonie Van Leeuwenhoek 2014, 106, 891-899. [CrossRef] [PubMed]

6. Singh, J.S. Microbes: The chief ecological engineers in reinstating equilibrium in degraded ecosystems. Agric. Ecosyst. Environ. 2015, 203, 80-82. [CrossRef]

7. Zhang, P.; Li, L.; Pan, G.; Ren, J. Soil quality changes in land degradation as indicated by soil chemical, biochemical and microbiological properties in a karst area of southwest Guizhou, China. Environ. Geol. 2006, 51, 609-619. [CrossRef]

8. Neuenkamp, L.; Prober, S.M.; Price, J.N.; Zobel, M.; Standish, R.J. Benefits of mycorrhizal inoculation to ecological restoration depend on plant functional type, restoration context and time. Fungal Ecol. 2019, 40, 140-149. [CrossRef]

9. Van der Heijden, M.G.A.; Horton, T.R. Socialism in soil? The importance of mycorrhizal fungal networks for facilitation in natural ecosystems. J. Ecol. 2009, 97, 1139-1150. [CrossRef]

10. Rashid, M.I.; Mujawar, L.H.; Shahzad, T.; Almeelbi, T.; Ismail, I.M.; Oves, M. Bacteria and fungi can contribute to nutrients bioavailability and aggregate formation in degraded soils. Microbiol. Res. 2016, 183, $26-41$. [CrossRef]

11. Classen, A.T.; Sundqvist, M.K.; Henning, J.A.; Newman, G.S.; Moore, J.A.M.; Cregger, M.A.; Moorhead, L.C.; Patterson, C.M. Direct and indirect effects of climate change on soil microbial and soil microbial-plant interactions: What lies ahead? Ecosphere 2015, 6, 21. [CrossRef]

12. Wehner, J.; Antunes, P.M.; Powell, J.R.; Mazukatow, J.; Rillig, M.C. Plant pathogen protection by arbuscular mycorrhizas: A role for fungal diversity? Pedobiologia 2010, 53, 197-201. [CrossRef]

13. Rillig, M.C.; Aguilar-Trigueros, C.A.; Bergmann, J.; Verbruggen, E.; Veresoglou, S.D.; Lehmann, A. Plant root and mycorrhizal fungal traits for understanding soil aggregation. New Phytol. 2015, 205, 1385-1388. [CrossRef] [PubMed]

14. Calderon, K.; Spor, A.; Breuil, M.C.; Bru, D.; Bizouard, F.; Violle, C.; Barnard, R.L.; Philippot, L. Effectiveness of ecological rescue for altered soil microbial communities and functions. ISME J. 2017, 11, 272-283. [CrossRef] [PubMed]

15. Ambrosini, A.; de Souza, R.; Passaglia, L.M.P. Ecological role of bacterial inoculants and their potential impact on soil microbial diversity. Plant Soil 2015, 400, 193-207. [CrossRef]

16. SER. The SER international primer on ecological restoration. Ecol. Restor 2004, 2, $206-207$.

17. Sultan, D.; Tsunekawa, A.; Haregeweyn, N.; Adgo, E.; Tsubo, M.; Meshesha, D.T.; Masunaga, T.; Aklog, D.; Fenta, A.A.; Ebabu, K. Impact of Soil and Water Conservation Interventions on Watershed Runoff Response in a Tropical Humid Highland of Ethiopia. Environ. Manag. 2018, 61, 860-874. [CrossRef]

18. Damene, S.; Tamene, L.; Vlek, P.L.G. Performance of exclosure in restoring soil fertility: A case of Gubalafto district in North Wello Zone, northern highlands of Ethiopia. CATENA 2013, 101, 136-142. [CrossRef] 
19. Aerts, R.; Negussie, A.; Maes, W.; November, E.; Hermy, M.; Muys, B. Restoration of dry Afromontane forest using pioneer shrubs as nurse-plants for Olea europaea ssp. cuspidata. Restor. Ecol. 2007, 15, 129-138. [CrossRef]

20. Delelegn, Y.T.; Purahong, W.; Sanden, H.; Yitaferu, B.; Godbold, D.L.; Wubet, T. Transition of Ethiopian highland forests to agriculture-dominated landscapes shifts the soil microbial community composition. BMC Ecol. 2018, 18, 58. [CrossRef]

21. Wassie, A.; Sterck, F.J.; Bongers, F. Species and structural diversity of church forests in a fragmented Ethiopian Highland landscape. J. Veg. Sci. 2010, 21, 938-948. [CrossRef]

22. Abiyu, A.; Teketay, D.; Glatzel, G.; Gratzer, G. Seed production, seed dispersal and seedling establishment of two afromontane tree species in and around a church forest: Implications for forest restoration. For. Ecosyst. 2016, 3, 16. [CrossRef]

23. Berhane, A.; Totland, Ø.; Moe, S.R. Woody plant assemblages in isolated forest patches in a semiarid agricultural matrix. Biodivers. Conserv. 2013, 22, 2519-2535. [CrossRef]

24. Aerts, R.; Overtveld, K.; November, E.; Wassie, A.; Abiyu, A.; Demissew, S.; Daye, D.D.; Giday, K.; Haile, M.; TewoldeBerhan, S.; et al. Conservation of the Ethiopian church forests: Threats, opportunities and implications for their management. Sci. Total Environ. 2016, 551. [CrossRef]

25. Wassie, A.; Sterck, F.J.; Teketay, D.; Bongers, F. Tree Regeneration in Church Forests of Ethiopia: Effects of Microsites and Management. Biotropica 2009, 41, 110-119. [CrossRef]

26. Wassie, A.; Sterck, F.J.; Teketay, D.; Bongers, F. Effects of livestock exclusion on tree regeneration in church forests of Ethiopia. For. Ecol. Manag. 2009, 257, 765-772. [CrossRef]

27. Friis, I. Forests and Forest Trees of Northeast Tropical Africa: Their Natural Habitats and Distribution Patterns in Ethiopia, Djibouti and Somalia; Her Majesty's Stationery Office: London, UK, 1992.

28. Tesemma, A.B. Useful Trees and Shrubs for Ethiopia: Identification, Propagation and Management for 17 Agro-Climatic Zones; Regional Land Management Unit.: Nairobi, Kenya, 2007.

29. Aynekulu, E.; Denich, M.; Tsegaye, D.; Aerts, R.; Neuwirth, B.; Boehmer, H.J. Dieback affects forest structure in a dry Afromontane forest in northern Ethiopia. J. Arid Environ. 2011, 75, 499-503. [CrossRef]

30. Yibeltal, M.; Tsunekawa, A.; Haregeweyn, N.; Adgo, E.; Meshesha, D.T.; Aklog, D.; Masunaga, T.; Tsubo, M.; Billi, P.; Vanmaercke, M.; et al. Analysis of long-term gully dynamics in different agro-ecology settings. Catena 2019, 179, 160-174. [CrossRef]

31. Cardelús, C.; Scull, P.; Hair, J.; Baimas-George, M.; Lowman, M.; Eshete, A. A Preliminary Assessment of Ethiopian Sacred Grove Status at the Landscape and Ecosystem Scales. Diversity 2013, 5, 320-334. [CrossRef]

32. Mekonnen, G. Soil Characterization Classification and Mapping of Three Twin Watersheds in the Upper Blue Nile basin, Ethiopia; Final Project Report; Amhara Design and Supervision Works Enterprise: Bahir Dar, Ethiopia, 2016.

33. McNamara, N.P.; Black, H.I.J.; Beresford, N.A.; Parekh, N.R. Effects of acute gamma irradiation on chemical, physical and biological properties of soils. Appl. Soil Ecol. 2003, 24, 117-132. [CrossRef]

34. Yibeltal, M.; Tsunekawa, A.; Haregeweyn, N.; Adgo, E.; Meshesha, D.T.; Masunaga, T.; Tsubo, M.; Billi, P.; Ebabu, K.; Fenta, A.A.; et al. Morphological characteristics and topographic thresholds of gullies in different agro-ecological environments. Geomorphology 2019, 341, 15-27. [CrossRef]

35. Orlowsky, B. iki. dataclim: Consistency, Homogeneity and SummaryStatistics of Climatological Data. R Package Version 1.0. 2014. Available online: https://rdrr.io/cran/iki.dataclim/ (accessed on 4 September 2019).

36. Chandra, N.; Kumar, S. Antibiotics Producing Soil Microorganisms. In Antibiotics and Antibiotics Resistance Genes in Soils: Monitoring, Toxicity, Risk Assessment and Management; Hashmi, M.Z., Strezov, V., Varma, A., Eds.; Springer International Publishing: Cham, Switzerland, 2017; pp. 1-18. [CrossRef]

37. Bray, R.H.; Kurtz, L.T. Determination of total, organic, and available forms of phosphorus in soils. Soil Sci. 1945, 59, 39-46. [CrossRef]

38. Levy, G.J.; Mamedov, A.I. High-Energy-Moisture-Characteristic Aggregate Stability as a Predictor for Seal Formation. Soil Sci. Soc. Am. J. 2002, 66, 1603-1609. [CrossRef]

39. Bouyoucos, G.j. Directions For Making Mechanical Analyses Of Soils By The Hydrometer Method. Soil Sci. 1936, 42, 225-230. [CrossRef]

40. Klindworth, A.; Pruesse, E.; Schweer, T.; Peplies, J.; Quast, C.; Horn, M.; Glockner, F.O. Evaluation of general $16 \mathrm{~S}$ ribosomal RNA gene PCR primers for classical and next-generation sequencing-based diversity studies. Nucleic Acids Res. 2013, 41, e1. [CrossRef] [PubMed] 
41. Toju, H.; Tanabe, A.S.; Yamamoto, S.; Sato, H. High-coverage ITS primers for the DNA-based identification of ascomycetes and basidiomycetes in environmental samples. PLoS ONE 2012, 7, e40863. [CrossRef]

42. Tian, Q.; Taniguchi, T.; Shi, W.Y.; Li, G.; Yamanaka, N.; Du, S. Land-use types and soil chemical properties influence soil microbial communities in the semiarid Loess Plateau region in China. Sci. Rep. 2017, 7, 45289. [CrossRef]

43. Tedersoo, L.; Sánchez-Ramírez, S.; Kõljalg, U.; Bahram, M.; Döring, M.; Schigel, D.; May, T.; Ryberg, M.; Abarenkov, K. High-level classification of the Fungi and a tool for evolutionary ecological analyses. Fungal Divers. 2018, 90, 135-159. [CrossRef]

44. Caporaso, J.G.; Kuczynski, J.; Stombaugh, J.; Bittinger, K.; Bushman, F.D.; Costello, E.K.; Fierer, N.; Peña, A.G.; Goodrich, J.K.; Gordon, J.I.; et al. QIIME allows analysis of high-throughput community sequencing data. Nat. Methods 2010, 7, 335-336. [CrossRef]

45. Bengtsson-Palme, J.; Ryberg, M.; Hartmann, M.; Branco, S.; Wang, Z.; Godhe, A.; De Wit, P.; Sánchez-García, M.; Ebersberger, I.; de Sousa, F.; et al. Improved software detection and extraction of ITS1 and ITS2 from ribosomal ITS sequences of fungi and other eukaryotes for analysis of environmental sequencing data. Methods Ecol. Evol. 2013. [CrossRef]

46. Edgar, R.C. Search and clustering orders of magnitude faster than BLAST. Bioinformatics 2010, 26, $2460-2461$. [CrossRef] [PubMed]

47. Edgar, R.C.; Haas, B.J.; Clemente, J.C.; Quince, C.; Knight, R. UCHIME improves sensitivity and speed of chimera detection. Bioinformatics 2011, 27, 2194-2200. [CrossRef] [PubMed]

48. Team, R.C. R: A Language and Environment for Statistical Computing; R Foundation for Statistical Computing: Vienna, Austria, 2015.

49. De Mendiburu, M.F. Package 'agricolae'. R Package, Version 2019, 1.2-1. Available online: https://tarwi. lamolina.edu.pe/ \{\}fmendiburu/ (accessed on 4 September 2019).

50. Allignol, A.; Latouche, A. CRAN Task View: Survival Analysis. Version 2017-04-25. Available online: https://CRAN.R-project.org/view=Survival.2017 (accessed on 4 September 2019).

51. Oksanen, J.; Blanchet, F.; Friendly, M.; Kindt, R.; Legendre, P.; McGlinn, D.; Minchin, P.; O’Hara, R.; Simpson, G.; Solymos, P. vegan: Community Ecology Package. R Package Version 2.5-2. 2018. Available online: https://rdrr.io/cran/vegan/ (accessed on 4 September 2019).

52. Brady, N.; Ray, W. The Nature and Properties of Soils, 15th ed.; Pearson Education: London, UK, 2017.

53. Wubet, T.; Kottke, I.; Teketay, D.; Oberwinkler, F. Mycorrhizal status of indigenous trees in dry Afromontane forests of Ethiopia. For. Ecol. Manag. 2003, 179, 387-399. [CrossRef]

54. Zhang, Q.; Zhang, L.; Weiner, J.; Tang, J.; Chen, X. Arbuscular mycorrhizal fungi alter plant allometry and biomass-density relationships. Ann. Bot. 2011, 107, 407-413. [CrossRef] [PubMed]

55. Altmann, D.; Stief, P.; Amann, R.; De Beer, D.; Schramm, A. In situ distribution and activity of nitrifying bacteria in freshwater sediment. Environ. Microbiol. 2003, 5, 798-803. [CrossRef] [PubMed]

56. Li, Y.; Chapman, S.J.; Nicol, G.W.; Yao, H. Nitrification and nitrifiers in acidic soils. Soil Biol. Biochem. 2018, 116, 290-301. [CrossRef]

57. Deacon, J. Fungal Biology. Fungal Biol. 2005. [CrossRef]

58. Jia, T.; Wang, R.; Fan, X.; Chai, B. A Comparative Study of Fungal Community Structure, Diversity and Richness between the Soil and the Phyllosphere of Native Grass Species in a Copper Tailings Dam in Shanxi Province, China. Appl. Sci. 2018, 8, 1297. [CrossRef]

59. Hewelke, E.; Górska, E.B.; Gozdowski, D.; Korc, M.; Olejniczak, I.; Prędecka, A. Soil Functional Responses to Natural Ecosystem Restoration of a Pine Forest Peucedano-Pinetum after a Fire. Forests 2020, 11, 286. [CrossRef]

60. Garau, G.; Morillas, L.; Roales, J.; Castaldi, P.; Mangia, N.P.; Spano, D.; Mereu, S. Effect of monospecific and mixed Mediterranean tree plantations on soil microbial community and biochemical functioning. Appl. Soil Ecol. 2019, 140, 78-88. [CrossRef]

61. Ushio, M.; Kitayama, K.; Balser, T.C. Tree species-mediated spatial patchiness of the composition of microbial community and physicochemical properties in the topsoils of a tropical montane forest. Soil Biol. Biochem. 2010, 42, 1588-1595. [CrossRef]

62. Prescott, C.E.; Grayston, S.J. Tree species influence on microbial communities in litter and soil: Current knowledge and research needs. For. Ecol. Manag. 2013, 309, 19-27. [CrossRef] 
63. Haichar, F.E.Z.; Santaella, C.; Heulin, T.; Achouak, W. Root exudates mediated interactions belowground. Soil Biol. Biochem. 2014, 77, 69-80. [CrossRef]

64. Philippot, L.; Raaijmakers, J.M.; Lemanceau, P.; van der Putten, W.H. Going back to the roots: The microbial ecology of the rhizosphere. Nat. Rev. Microbiol. 2013, 11, 789-799. [CrossRef] [PubMed]

65. Smith, S.E.; Jakobsen, I.; Gronlund, M.; Smith, F.A. Roles of arbuscular mycorrhizas in plant phosphorus nutrition: Interactions between pathways of phosphorus uptake in arbuscular mycorrhizal roots have important implications for understanding and manipulating plant phosphorus acquisition. Plant Physiol. 2011, 156, 1050-1057. [CrossRef]

66. St-Denis, A.; Kneeshaw, D.; Bélanger, N.; Simard, S.; Laforest-Lapointe, I.; Messier, C. Species-specific responses to forest soil inoculum in planted trees in an abandoned agricultural field. Appl. Soil Ecol. 2017, 112, 1-10. [CrossRef]

67. Abiyu, A.; Teketay, D.; Glatzel, G.; Aerts, R.; Gratzer, G. Restoration of degraded ecosystems in the Afromontane highlands of Ethiopia: Comparison of plantations and natural regeneration. South. For. 2017, 79, 103-108. [CrossRef]

68. Asmelash, F.; Bekele, T.; Birhane, E. The Potential Role of Arbuscular Mycorrhizal Fungi in the Restoration of Degraded Lands. Front. Microbiol. 2016, 7, 1095. [CrossRef]

69. Atkin, O.K.; Loveys, B.R.; Atkinson, L.J.; Pons, T.L. Phenotypic plasticity and growth temperature: Understanding interspecific variability. J. Exp. Bot. 2006, 57, 267-281. [CrossRef]

70. Jiang, Y.; Wang, L. Pattern and control of biomass allocation across global forest ecosystems. Ecol. Evol. 2017, 7, 5493-5501. [CrossRef]

71. Eziz, A.; Yan, Z.; Tian, D.; Han, W.; Tang, Z.; Fang, J. Drought effect on plant biomass allocation: A meta-analysis. Ecol. Evol. 2017, 7, 11002-11010. [CrossRef] [PubMed]

72. Zandavalli, R.B.; Dillenburg, L.R.; de Souza, P.V.D. Growth responses of Araucaria angustifolia (Araucariaceae) to inoculation with the mycorrhizal fungus Glomus clarum. Appl. Soil Ecol. 2004, 25, 245-255. [CrossRef]

73. Delelegn, Y.T.; Purahong, W.; Blazevic, A.; Yitaferu, B.; Wubet, T.; Göransson, H.; Godbold, D.L. Changes in land use alter soil quality and aggregate stability in the highlands of northern Ethiopia. Sci. Rep. 2017, 7, 1-12. [CrossRef] [PubMed]

74. Caravaca, F.; Lax, A.; Albaladejo, J. Aggregate stability and carbon characteristics of particle-size fractions in cultivated and forested soils of semiarid Spain. Soil Tillage Res. 2004, 78, 83-90. [CrossRef]

75. Daynes, C.N.; Field, D.J.; Saleeba, J.A.; Cole, M.A.; McGee, P.A. Development and stabilisation of soil structure via interactions between organic matter, arbuscular mycorrhizal fungi and plant roots. Soil Biol. Biochem. 2013, 57, 683-694. [CrossRef]

76. Obalum, S.E.; Chibuike, G.U.; Peth, S.; Ouyang, Y. Soil organic matter as sole indicator of soil degradation. Environ. Monit. Assess. 2017, 189, 176. [CrossRef]

77. Blankinship, J.C.; Fonte, S.J.; Six, J.; Schimel, J.P. Plant versus microbial controls on soil aggregate stability in a seasonally dry ecosystem. Geoderma 2016, 272, 39-50. [CrossRef]

78. Bearden, B. Influence of arbuscular mycorrhizal fungi on soil structure and soil water characteristics of vertisols. Plant Soil 2001, 229, 245-258. [CrossRef]

(C) 2020 by the authors. Licensee MDPI, Basel, Switzerland. This article is an open access article distributed under the terms and conditions of the Creative Commons Attribution (CC BY) license (http://creativecommons.org/licenses/by/4.0/). 